\title{
A functional approach to the ecology of Atlantic Basque streams
}

\author{
Arturo Elosegi ${ }^{1}$, Ana Basaguren ${ }^{2} \&$ Jesús Pozo ${ }^{3}$ \\ Department of Plant Biology and Ecology, Faculty of Science and Technology, University of the Basque \\ Country, POBox 644, 48080 Bilbao, Spain \\ e-mail: 19arturo.elosegi@ehu.es, ${ }^{2}$ ana.basaguren@ehu.es,3jesus.pozo@ehu.es
}

\begin{abstract}
Most research on stream ecology is focused on structural characteristics of stream ecosystems, while less effort is being dedicated to the study of their functional attributes. The laboratory of stream ecology, at the University of the Basque Country, has been researching streams from an ecosystem perspective, including both structural and functional properties. Here we review the research done so far. Basque streams running to the Atlantic Ocean are short, steep, and flashy, and tend to show large spatial variations as a result of changes in geology and soil use. Where they exist, riparian forests limit the growth of primary producers and are a source of coarse particulate organic matter, an important food resource for consumers. The trophic structure of benthic macroinvertebrate communities changes downstream with resource abundance, although temporal variations of both resources and consumers are not coupled. Gut content analyses show the diet of some species to change with instar development, and thus, warn against the indiscriminate assignation of trophic categories. Floods are important disturbances, affecting primary producers, consumers, and ecosystem processes. Other important disturbances are changes in riparian vegetation, which can profoundly affect the food resources of stream communities. This basic knowledge has been used to develop new tools to assess stream functional impairment, based in two pivotal functions: litter breakdown and whole stream metabolism. Both eutrophication and changes in riparian vegetation affect the use of leaf litter, and thus impact stream functioning making litter breakdown a promising tool for stream monitoring. On the other hand, whole stream metabolism is affected by many human impacts, and can be measured continuously in modern gauging stations, thus allowing for almost real-time monitoring of ecosystem functioning. We hope these and other functional properties will be built into routine monitoring schemes, which will therefore look at both the structural and functional sides of stream ecosystems.
\end{abstract}

Keywords: Basque streams, structural and functional properties, leaf breakdown and metabolism processes.

\section{RESUMEN}

La mayor parte de los trabajos sobre ecología de ríos se ha centrado en características estructurales, y se ha dedicado menos esfuerzo a estudiar los atributos funcionales de los ecosistemas fluviales. El laboratorio de ecología de ríos, en la Universidad del País Vasco, ha estado estudiando arroyos desde una perspectiva ecosistémica, incluyendo propiedades estructurales y funcionales, y mostramos aquí una revisión de los trabajos llevados a cabo. Los ríos vascos que drenan al Océano Atlántico son cortos, de fuerte pendiente, y torrenciales, y tienden a mostrar fuertes variaciones espaciales a consecuencia de cambios en geología y usos del suelo. Cuando existen, los bosques riparios limitan la capacidad de crecimiento de los productores primarios, y son fuente de materia orgánica particulada gruesa, un importante recurso alimentario para los consumidores. La estructura trófica de las comunidades de macroinvertebrados bentónicos cambia aguas abajo con la abundancia de recursos, aunque las variaciones temporales de recursos y consumidores no están sincronizadas. El análisis de contenidos digestivos muestra que la dieta de algunas especies cambia con el grado de desarrollo larvario, y en consecuencia, previene contra la asignación indiscriminada de categorías tróficas. Las riadas son perturbaciones importantes que afectan tanto a productores primarios como a consumidores, o a procesos a nivel de ecosistema. Otras perturbaciones importantes son los cambios en la vegetación riparia, que pueden afectar profundamente los recursos alimentarios de las comunidades fluviales. Este conocimiento básico se ha utilizado para desarrollar nuevas herramientas de evaluación del estado de los rios, basadas en dos funciones claves: la descomposición de hojarasca y el metabolismo del río. Tanto la eutrofización como los cambios en la vegetación de ribera afectan el uso de la hojarasca y, por tanto, impactan en el funcionamiento del ecosistema, lo que hace de la descomposición de hojarasca una herramienta prometedora para el seguimiento de los rios. Por otra parte, el metabolismo del ecosistema fluvial es afectado por muchos impactos humanos, y puede ser medido en continuo en estaciones de aforo modernas, lo que permite seguir el funcionamiento del ecosistema casi a tiempo real. Esperamos que estas y otras propiedades funcionales se integrarán en los protocolos de seguimiento rutinario, que asi tendrán en cuenta tanto el lado estructural como el funcional de los ecosistemas fluviales.

Palabras clave: Ríos vascos, propiedades estructurales, propiedades funcionales, descomposición de hojarasca, metabolismo. 


\section{INTRODUCTION}

For many years, research on stream ecology has focused mainly on the structural characteristics of ecosystems, like water chemistry, physical habitat or abundance, and structure of biotic communities (Plafkin et al., 1989; Rosenberg \& Resh, 1992; Rosgen, 1996; Fairweather, 1999; Maddock, 1999). In contrast, functional attributes of stream ecosystems received less attention, and were often inferred from structural characteristics, like the widespread use of invertebrate functional feeding groups (Merritt \& Cummins, 1996) to indirectly gather information on stream function (e.g. Rawer-Jost et al., 2000). This bias toward ecosystem structure and neglect of ecosystem function is reflected in most streammonitoring studies. These studies are typically based on biotic or other structural indices, or in the case of indices of biotic integrity (IBI, Karr, 1981), infer stream dysfunctions from structural attributes of fish or invertebrate communities. Even the European Water Framework Directive (WFD, 2000/60/EC), the most recent and ecologically sound framework for Community action in water policy for protection and restoration of aquatic ecosystems, relies heavily on structural stream characteristics, probably because standard functional metrics are still lacking. However, some effects of disturbances could go unnoticed if only community composition is measured, especially those resulting in longterm responses in the ecosystems.

According to Young et al. (2004), including functional indicators together with structural variables for regular monitoring of river health has several advantages: Firstly, the evaluation of both structural and functional components of an ecosystem gives a wider and more complete view of ecosystem health. Secondly, functional variables give a true measure of ecosystem integral status. As an example, leaf litter decomposition is influenced by hydrology, water temperature, nutrient concentrations, etc., and many kinds of organisms are involved (e.g., bacteria, fungi, invertebrates, fishes).

The group of Stream Ecology at the Faculty of Science and Technology, University of the

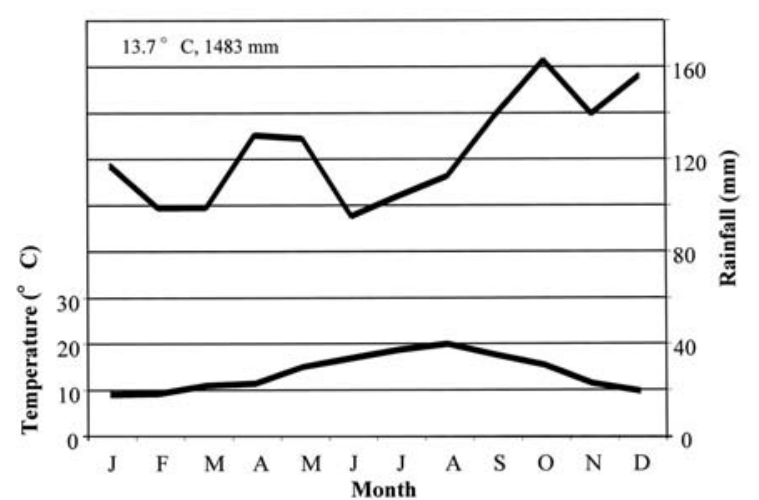

Figure 1. Climate diagram of San Sebastian for the period 1992-2003. Data from Eustat (www.eustat.es). Diagrama climático de San Sebastián para el periodo 1992-2003. Datos de Eustat (www.eustat.es).

Basque Country, is researching streams in the Basque Country and Cantabria from an ecosystem perspective since 1988. Our main goal is to know the basic structure and function of streams running to the Gulf of Biscay, and how they are affected by human activities in the basin. Here we review some of the functional characteristics of these streams, with special emphasis on the transport and processing of materials and on production.

\section{PHYSICAL SETTING}

The Basque mountains are relatively low (highest elevations ca. 1500 m.-a.s.1.) and are composed of sedimentary rocks of Jurassic, Cretaceous, and Tertiary age (reefal limestone, sandstones and marls), along with some granitic, basaltic, and metamorphic outcrops, uplifted during the Pyrenean Orogeny. They are very close to the coast and thus, valleys are narrow, and rivers short (ca. $40 \mathrm{~km}$ ), steep, and straight. The climate of the whole area is under the influence of the Atlantic Ocean, and therefore, is relatively mild and humid (Fig. 1). A twofold gradient in rainfall is usually observed: a southward increase in rainfall as the moist oceanic air rises over the mountain slopes, and superimposed, an eastward increase toward the corner of the Gulf of Biscay. As a result, average annual rainfall ranges from below $1500 \mathrm{~mm}$ in the area of Bilbao to over 


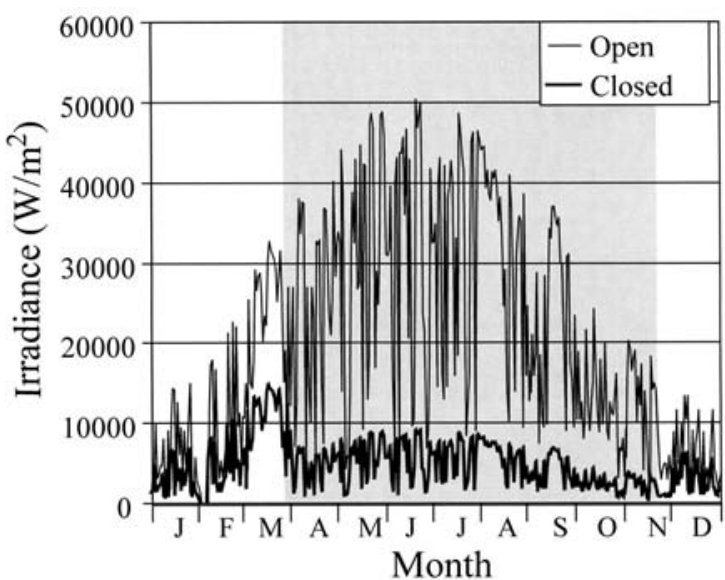

Figure 2. Weekly solar irradiation at Ordizia during 2003. Open: measured data. Closed: estimated irradiation under a closed canopy. Shaded area represents the period when the forest has leaves. Irradiacion solar semanal en Ordizia durante 2003. Open: datos medidos. Closed: irradiación estimada bajo un dosel cerrado. El área sombreada representa el periodo en que el bosque tiene hojas.

$3000 \mathrm{~mm}$ in the mountains near the east end of Guipuscoa (Anonimous, 1995). Irradiance shows the typical pattern of mid latitudes, but is much affected by weather (Fig. 2). As a result of heavy rainfall and short, steep valleys Basque streams are quite flashy (Fig. 3). Around 1.8 million people live in this area (density $=400 / \mathrm{km}^{2}$ ), mainly in cities. Both heavy (steel and paper factories) and light industry (machine-tool, car components) are abundant in one of the most industrialised Spanish regions. Most rural areas are covered by intensive tree plantations of Monterey pine (Pinus radiata D. Don) and blue gum (Eucalyptus globulus Labill.), harvested in short rotations with heavy machinery. Native forests consist mainly of beech forests on the wet uplands; some oak stands on the lowlands, and some holm oak forests on karstic outcrops. There are also a number of farms and dairies, most of them growing cattle and sheep. As a result of all these activities in such a small territory, most streams were severely polluted after the mid $20^{\text {th }}$-century. Over the last 20 years, clean production systems and domestic and industrial water treatment plants have been implemented in most basins, resulting in a significant improvement of water quality (Arluziaga, 2002).

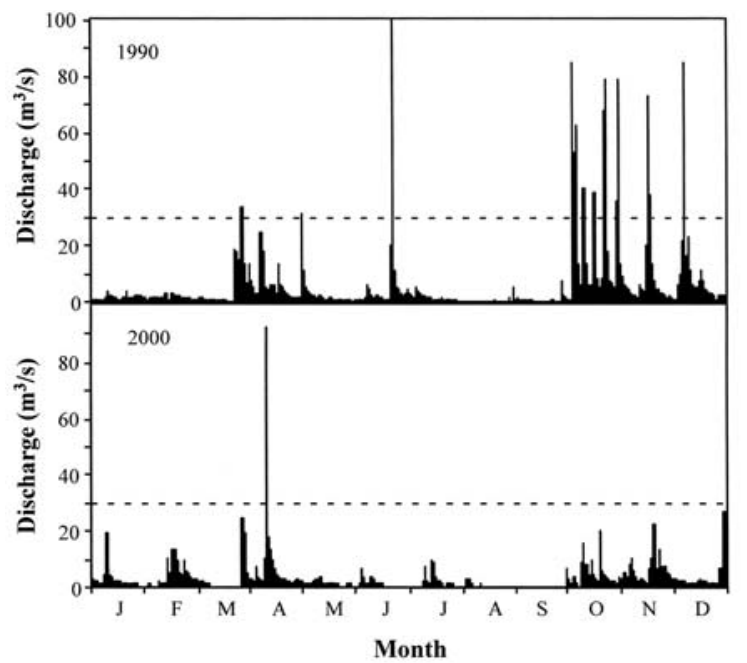

Figure 3. Hydrograph of the Agüera stream in a wet and in a dry year. The stippled line marks the level of bed-moving floods according to Elósegui \& Pozo (1998). Hidrograma del rio Agüera en un año húmedo y otro seco. La línea discontinua marca el nivel de las riadas que remueven el sedimento según Elósegui \& Pozo (1998).

Nowadays, some rivers are still severely degraded, whereas others have recovered and have been chosen for reintroduction programs, as it is the case of salmon (Galera \& Antón, 2001). Apart from chemical pollution, many Basque streams are severely affected by canalisation and degradation of river margins and floodplains (Basque Government, 2003).

\section{THE AGÜERA AS A MODEL STREAM}

The Agüera, a stream at the border between Biscay and Cantabria, has been studied over the last 17 years by the group of Stream Ecology at the University of the Basque Country. It is a relatively well-preserved stream and thus, well suited as a model for the natural functioning of Basque streams (Elosegi et al., 2002). In the Agüera, large spatial variations in water chemistry reflect changes in geology and soil uses, and from a temporal perspective, seasonality is relatively small, main changes being related to relatively unpredictable floods, or to diel variations (Elósegui \& Pozo, 1994; Elósegui et al., 1997).

Riparian forests are present along most of the Agüera stream, with the exception of some rea- 

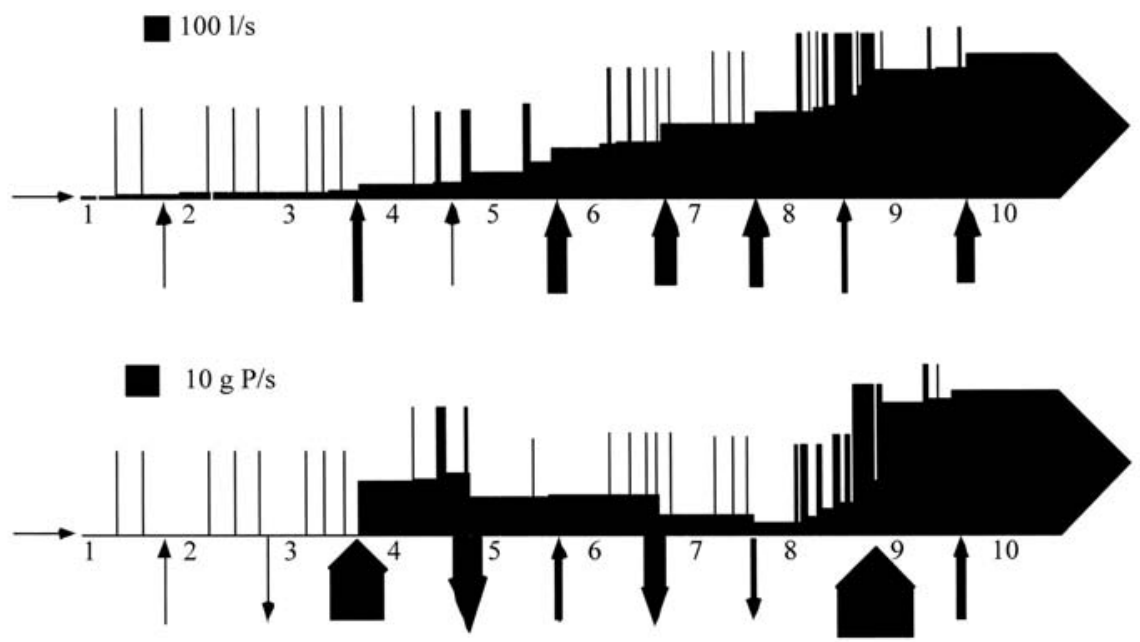

Figure 4. Mass-balance of water (top) and dissolved phosphorus (bottom) along the Agüera stream on July 10, 1990. Numbers are sampling sites along the stream axis; vertical bars from the top represent inputs from the tributaries, and arrows on the bottom represent the net balance of other inputs and outputs. In the case of water, inputs are mainly groundwater. In the case of phosphorus, most inputs come from sewers, and outputs reflect in-stream nutrient withdrawal (self-purification). Note the differences between both variables, and the important retention of phosphorus in the mid reaches of the Agüera stream. Balance de masas de agua (arriba) y fósforo disuelto (abajo) a lo largo del río Agüera el 10 de julio de 1990. Los números representan estaciones de muestreo a lo largo del eje principal, las barras verticales de arriba la contribución de los afluentes, y las flechas de abajo el balance neto de otras entradas y salidas. En el caso del agua las entradas son fundamentalmente de agua subterránea. En el caso del fósforo, la mayor parte de las entradas proviene de colectores, y las salidas reflejan la retirada de fósforo en el cauce (autodepuración). Observense las diferencias entre ambas variables, y la importante retención de fósforo en tramos intermedios del Agüera.

ches close to villages (Elosegui, 1992). Therefore, periphytic biomass tends to be low except at open reaches affected by sewage water, where primary production can be high in long periods of base-flow (Elosegui \& Pozo, 1998). Izagirre \& Elosegi (2005) showed that at closed reaches the cycle of growth and abscission of riparian tree leaves control periphytic biomass, whereas discharge is the main temporal controller at open ones. As a result of contrasting rainfall patterns, inter-annual differences can be very large. In periods of large periphytic biomass, mid reaches of the Agüera stream can be highly retentive (Fig. 4), thus resulting in active selfpurification (Elosegui et al., 1995).

One important food source for consumers in forested streams, as is the present case, is allochthonous organic matter that enters the stream as coarse particulate organic matter (CPOM), fine particulate organic matter (FPOM) or dissolved organic matter (DOM). Both FPOM and DOM are also good indicators of intermediate disturbances and recovery in streams of the basin (Pozo et al., 1994; González \& Pozo, 1995).
Invertebrate communities tend to change their trophic structure along the main reach as a result of changes in resource abundance. Shredders and gatherers dominate the headwaters, and gatherers or scrapers, depending on shading and organic pollution, dominate the mid reaches (Riaño et al., 1993; Basaguren et al., 1996; González et al., 2003a). Nevertheless, the trophic structure of benthic invertebrate communities also changes throughout the year because of floods (Basaguren et al., 1996). From a trophic point of view, strict specialist invertebrates are rare. Gut content analyses indicate changes in diets with development, the main food in early instars being fine detritus, while other food types increased in importance in more developed instars (Riaño, 1998; Basaguren et al., 2002, Fig. $5)$. Thus, the grouping of all individuals of a population into a single trophic category might result in an oversimplification leading to imprecise trophic characterisation of the community (Basaguren et al., 2002). On the other hand, density and biomass of macroinvertebrates increase from headwaters to low reaches (Riaño et al., 


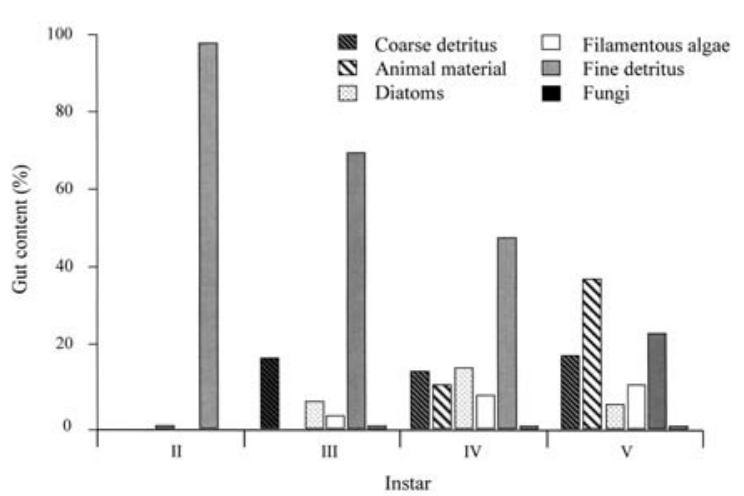

Figure 5. Changes in diet with instar development of Hydropsyche siltalai in the Agüera stream. Further information in Basaguren et al. (2002). Cambios de la dieta con el desarrollo larvario de Hydropsyche siltalai en el río Agüera. Más información en Basaguren et al. (2002).

1993; Basaguren et al., 1996; González et al., 2003a), and communities tend to be most diverse at mid and low reaches of the Agüera stream (González et al., 2003a).

The frequency, timing, and intensity of floods in such a flashy stream can have strong effects on benthic community resistance (Imbert et al., 2005). A comparison of the taxonomic structure of winter invertebrates at several sites during several years showed large inter-annual variability (Fig. 6), with floods being an important factor in controlling temporal changes of benthic invertebrates. This fact, together with the small seasonality, would explain the low synchrony of invertebrate biological cycles in the Agüera stream (Basaguren et al., 2002; González et al., $2003 b)$. Annual production of invertebrate species studied in the Agüera system fell well inside the values reported in the bibliography, and spatial patterns on production are mainly determined by in situ biomass (González et al., 2003 b, c).

As mentioned before, riparian forests cover most reaches of the Agüera stream, and therefore, the dynamics of allochthonous organic inputs are of great importance to the ecosystem. In the Agüera basin indigenous deciduous species coexist with vast plantations of exotic species (pine and eucalyptus), thus making it an ideal setting to assess the impact of vegetation changes on stream ecology. Eucalyptus plantations change the timing of litter inputs, which tend to peak in

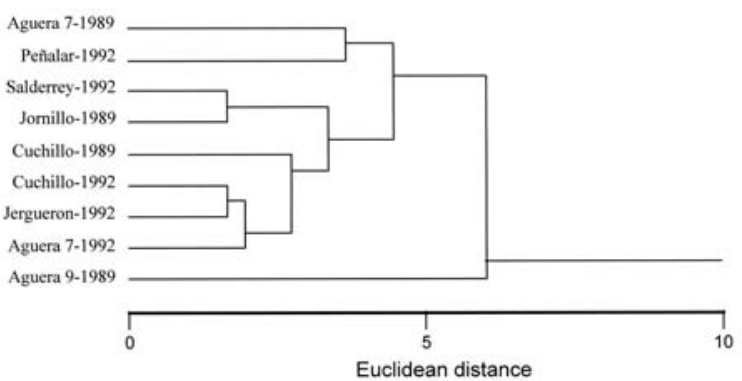

Figure 6. Structural similarity of winter invertebrate communities. Cuchillo, Salderrey, and Jornillo are 1st-order streams surrounded by deciduous forests; Jerguerón and Peñalar, 1storder streams surrounded by eucalyptus plantations; and Agüera 7 and Agüera 9, 3rd-order reaches with mixed vegetation. Riparian vegetation does not seem to affect the taxonomic structure of macroinvertebrate communities. Note that large inter-annual variability makes a reach more similar to another reach sampled the same year than to itself sampled in different years. Similaridad estructural de las comunidades invernales de macroinvertebrados bentónicos. Cuchillo, Salderrey y Jornillo son arroyos de orden 1 rodeados de bosques caducifolios, Jerguerón y Peñalar arroyos de orden 1 rodeados de plantaciones de eucaliptos, y Agüera 7 y Agüera 9 tramos de orden 3 y vegetación mixta. La vegetación de ribera no parece afectar a la estructura taxonómica de las comunidades de macroinvertebrados. Observese que la fuerte variabilidad interanual hace que un tramo sea más similar a otro muestreado el mismo año que a sí mismo en años diferentes.

summer, unlike in the deciduous forests, and, because summer low flows do not scour leaves downstream, they increase benthic storage of coarse particulate organic matter (Pozo et al., 1997; Molinero \& Pozo, 2004), which may facilitate its use by consumers and decomposers. However, because of its toxic oil glands, eucalyptus leaves are a poor resource for large streams detritivores (Canhoto \& Graça, 1999), and could therefore affect stream invertebrate communities. Furthermore, because eucalyptus plantations are harvested in extremely short rotation times, the impact of logging and road-building operations can also severely affect streams in areas where eucalyptus is abundant (Graça et al., 2002).

Most results on leaf litter decomposition processes in the Agüera stream have been already reviewed in a former work (Elosegi et al., 2002). In short, among the deciduous species, Alnus glutinosa (L.) Gaertner is processed faster than other species in the region such as Quercus robur L. or Castanea sativa Miller (Molinero et al., 1996; Pozo et al., 1998), a 
consequence of its higher quality (i.e. nutrient content) and soft texture (Pozo 1993; Molinero et al., 1996; Molinero \& Pozo 2002). On the other hand, decomposition of the exotic Eucalyptus globulus can be fast if dissolved nutrients, particularly phosphorus, are high, although leaf colonisation by decomposers (e.g. fungi) and detritivores (e.g. macroinvertebrates) can be delayed with respect to alder leaves (Basaguren \& Pozo 1994). So, the impact of eucalyptus plantations on stream communities is far from clear. New essays on this matter focus on applied science, aiming to design a tool for the assessment of stream ecological status based on litter decomposition. Some of the results are mentioned below.

\section{EXPANDING THE MODEL: NEW APPROACHES IN STREAM MONITORING}

Structure and function are the two sides of the ecosystem coin, and both are necessary to keep healthy ecosystems. Until now, most studies that monitored stream health relied heavily on structural components of the ecosystem. Recently there has been an awareness of the need to incorporate functional components into stream monitoring (Gessner \& Chauvet 2002; Young et al., 2004). The group of Stream Ecology has been recently involved in two projects aiming to develop functional tools to be included in stream monitoring. These projects are called RIVFUNCTION and METATOOL.

RIVFUNCTION (www.ladybio.ups-tlse.fr/ rivfunction/) was a project funded by the EU, involving 12 partners in 9 European countries, from Portugal to Sweden, and from Ireland to Romania. Its goals were to develop and disseminate a methodology based on litter breakdown to assess stream functional impairment. Litter breakdown is a pivotal function in stream ecosystems, as they are highly dependent on allochthonous organic inputs; furthermore, litter breakdown is sensitive to many stressors such as eutrophication, pollution, acidification, or changes in riparian vegetation, and the relatively easy and cheap measurements make it a good potential candidate for a monitoring tool.

RIVFUNCTION focused on two kinds of impacts that could affect stream function: changes in riparian vegetation and eutrophication, which can differ from country to country. To study the impact of changes in riparian vegetation, we selected 5 site pairs with similar chemistry but contrasting riparian vegetation (deciduous forests vs. eucalyptus plantations), and to assess the impact of eutrophication on litter breakdown, we selected 5 site pairs similar in size and water chemistry but differing in nutrient status. During October and November of 2002, freshly-fallen alder leaves were picked in the field, air dried, and $5.00 \pm 0.25 \mathrm{~g}$ of leaves were enclosed in coarse $(10 \mathrm{~mm})$ and fine $(0.5 \mathrm{~mm})$ mesh bags, and incubated in the streams from December $10^{\text {th }}, 2002$ to January $10^{\text {th }}, 2003$ (vegetation series), and from December $27^{\text {th }}$, 2002 to January 24th 2003 (eutrophication series). The end of these experiments was established at the time when an estimated loss of $50 \%$ of the material in coarse bags was reached at the reference sites. The remaining material was given in terms of ash-free dry mass (AFDM, $550{ }^{\circ} \mathrm{C}, 4 \mathrm{~h}$ ). Results showed that at nutrient-enriched sites microbial decomposition is enhanced, but invertebrate consumption is not; on the other hand, eucalyptus plantations slow down invertebrate breakdown, but do not have a significant effect on the role of microbes (Fig. 7). Thus, leaf breakdown is a process sensitive to anthropogenic impacts on streams, but before using it to assess stream functional integrity, target values of loss rates must be defined in a broad variety of reference environmental conditions.

METATOOL (METAbolism and periphyton of Cantabrian streams: a TOOL to assess the state of river ecosystems) is a project funded by the Spanish Department of Science and Technology, with researchers from the University of the Basque Country. Its objectives are to measure primary production and respiration of Basque streams, to study periphytic communities and their role in stream metabolism, to identify environmental factors governing metabolism, and to create a software to calculate metabolism auto- 

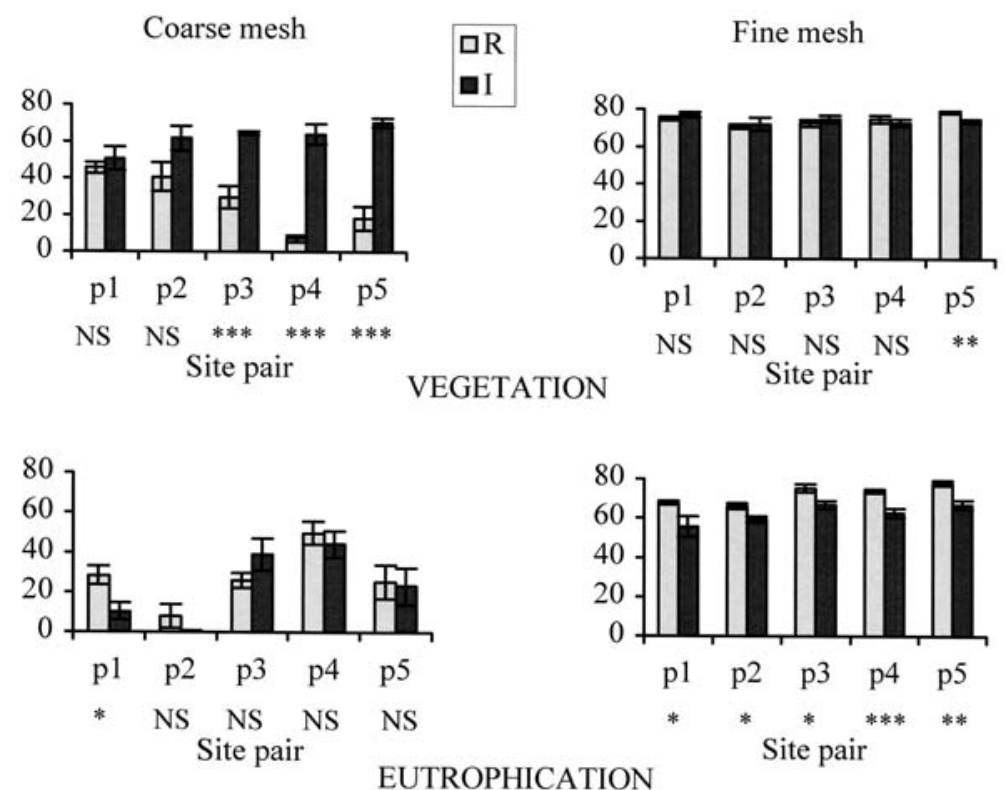

Figure 7. Ash-free dry mass remaining in alder litterbags after 4 weeks of exposure. Reference (R) streams are in grey, impacted streams (I) in black, and asterisks mark significant differences. Left, coarse mesh bags; right, fine mesh bags. Masa seca libre de cenizas remanente en bolsas de hojarasca de aliso tras 4 semanas de exposición. Arroyos de referencia (R) en gris, impactados (I) en negro. Los asteriscos marcan diferencias significativas. Izquierda, bolsas de malla gruesa, derecha, bolsas de malla fina.

matically from continuous oxygen monitoring. The Governments of the provinces of Biscay and Guipuscoa are involved in this project, as they are responsible of the so-called hydrometheorological net, consisting in a series of dischargegauging stations where several physical and chemical parameters are monitored continuously.

From continuous data on discharge, water temperature, and dissolved oxygen, we calculate whole ecosystem metabolism with the single station method (Odum, 1956), the re-aeration coefficient being calculated by the nighttime method by Hornberger \& Kelly (1975). These calculations are performed with RIVERMET (), an Excel-based software created for that purpose (Izagirre et al., in press), which can be freely downloaded at www.ehu.es/streamecology. Channel geomorphology is described from transversal transects, where total channel width and entrenchment, water depth, substrate category (silt, sand, gravel, pebble, cobble, boulder or bedrock), canopy cover (vertical projection), and water velocity at mid-depth (A.OTT Kempten Z30 current meter) are measured. Additionally, we measure bank and thalweg slope with a clinometer (Silva clino master) and a laser-beam level, and estimated changes in depth, wetted channel width, and water velocity resulting from changes in discharge with hydraulic modelling software HecRas 2.2.

Results show that there are large differences in periphytic biomass in Basque streams, summer maxima ranging from below 2 to almost $200 \mathrm{gAFDM} / \mathrm{m}^{2}$ (Fig. 8). Periphyton is especially abundant at the mid and low reaches of the Oria stream, but its biomass shows no significant correlation to stream metabolism. Summer gross primary production in Basque streams ranges from negligible to almost 20 $\mathrm{gO}_{2} / \mathrm{m}^{2} \mathrm{~d}$, and respiration to $35 \mathrm{gO}_{2} / \mathrm{m}^{2} \mathrm{~d}$. All Basque streams seem to be heterotrophic most of the time, and both gross primary production and ecosystem respiration are clearly related to the ecological status of the reach (Izagirre et al., in prep.). Nevertheless, stream metabolism shows high temporal variability, as it is strongly affected by floods, by changes in insolation, as well as by increases in water turbidity, which can often occur due to human activities. Thus, whole stream metabolism offers a powerful tool 
to assess stream function continuously, but some care must be taken in order to discern natural variability from human impacts.

\section{BEYOND THE MODEL: HOT TOPICS IN MANAGEMENT OF BASQUE STREAMS}

Basic knowledge on the functioning of ecosystems is essential to improve the management and status of our environment. Here we briefly discuss some topics drawn from the research so far done in Basque streams, that have potential implications for environmental management.

One of the aspects emerging from our studies is the high variability of the Agüera, and by extension, of Basque streams. Several sources of variability interact in complex patterns, and affect the different variables in a distinct way. Thus, all characteristics of stream ecosystems, from water chemistry to invertebrate production, are subject to large changes, at temporal scales that can range from diel to inter-annual. This variability makes it difficult to characterise streams and to measure their response to any environmental stress. Although it is a well-known fact, it has not been incorporated into monitoring studies as much as it should (Elosegui et al., 1997).

Streams are metabolically active reactors, not mere conduits. Riparian and in-channel nutrient withdrawal can be among the most important services rendered by streams in the future, as the costs of ever greater reduction of nutrient loads into streams rise sharply. Thus, it is necessary to gain insight into the stream characteristics that control retention capacity. There has been extensive research on the role of riparian forests on nutrient retention (Haycock et al., 1993; Sabater et al., 2003), but no guidelines exist as to the extent, characteristics, and management these forests should have in Basque streams. On the other hand, there is less knowledge on the factors governing in-channel nutrient retention, and especially, on how to optimise it.

Our studies also highlighted the important role of in-stream woody debris structuring the channel, creating habitats and retaining sediments and organic matter (Díez et al., 2000), and being a source of nutrients and energy (Díez et al., 2002). This role was pretty well known in the American Northwest, but much less evidence existed of its importance elsewhere, and in particular in European streams. Streams have been devoid of large wood during centuries, and strategies to enhance the amount and role of wood on stream function are necessary to restore streams (Kail \& Hering, 2005). The existing literature shows that wood is always important, even in reaches where it is extremely rare (Elosegi \& Johnson, 2003), and therefore efforts should be made to introduce it where it is absent. This should obviously be made with caution, as floating wood can block or damage bridges and other structures. Furthermore, people tend to perceive dead wood as an undesired feature of stream channels (Piégay et al., 2005), so any management activity meant to raise the amount of wood in streams should also target public awareness.

Our work on organic matter stressed the role of riparian forests on many aspects of stream ecology, as well as some important characteristics of these forests, like species composition and size structure. For example, the retention rate of alder leaves is higher than the rates of other tree species (Larrañaga et al., 2003), which may have implications when alders are removed from riparian areas. Furthermore, the loss of alder trees can reduce the storage of benthic particulated organic nitrogen (Molinero \& Pozo, 2002, 2004). Nevertheless, there is still a long way from our research to management guidelines. Many laws state that it is mandatory to keep riparian forests, but they most often give few clues about their characteristics, behind some minimum width, which is hardly based on ecological research. These laws should incorporate concepts like forest diversity, integrity, connectivity, size structure and management, and metrics to evaluate them should be built into methods to assess stream quality. For instance, QBR (Munné et al., 1998), the method to assess the quality of riparian forests most widely used in Spain, and also applied to Basque streams (Basque Government, 2003), totally neglects important aspects of riparian forest ecology, like 


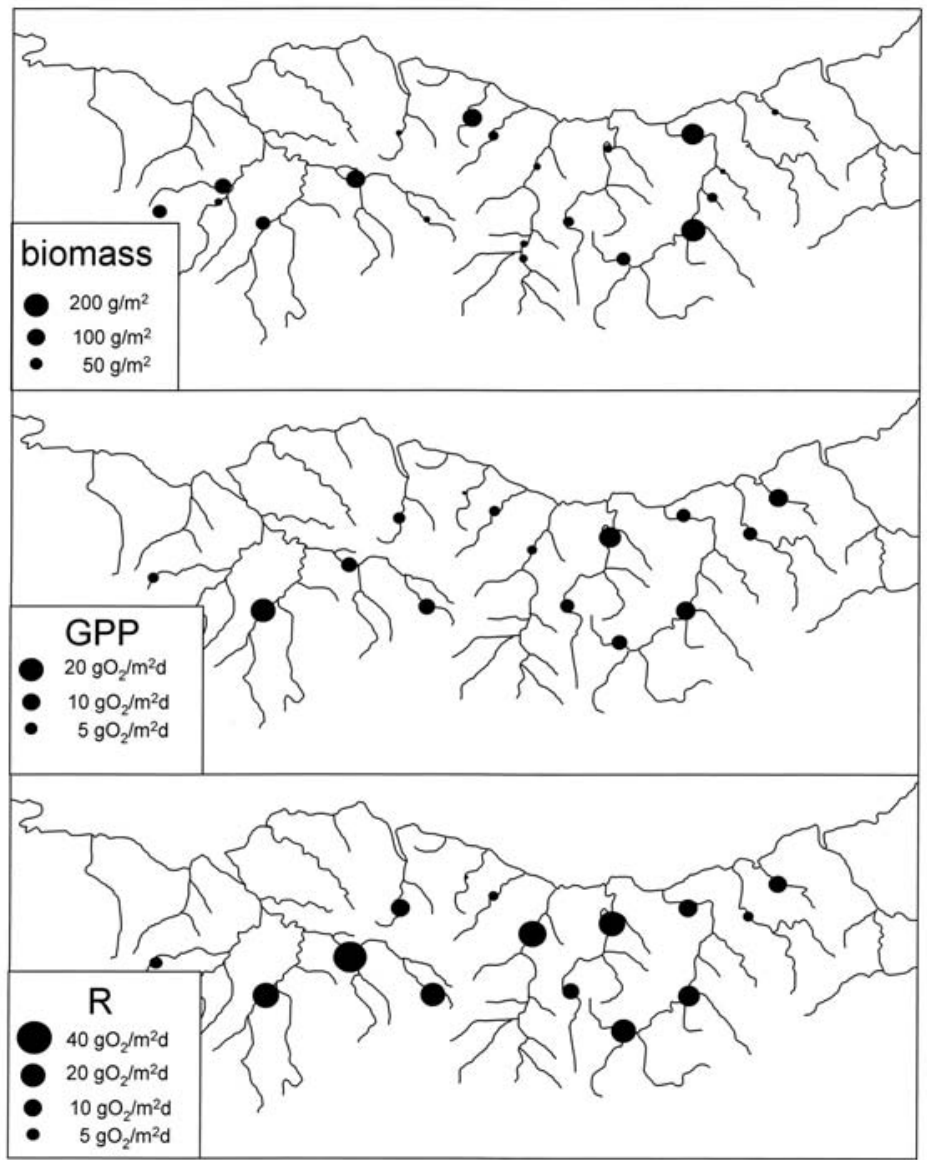

Figure 8. Periphytic biomass (top), gross primary production (mid) and ecosystem respiration (bottom) of Basque streams in summer 2003. Biomasa perifítica (arriba), producción primaria bruta (medio) y respiración del ecosistema (abajo) de ríos vascos en verano de 2003.

the vigour of seedling growth, even or uneven size- or age-distribution, abundance of dead wood, or presence of snags.

Connectivity is important for riparian forests, but also for in-channel communities. Basque streams show high temporal variability, and are subject to frequent disturbances, both natural and artificial. The most frequent natural disturbances are spates, but droughts can also affect small tributaries (Otermin et al., 2002). Artificial disturbances like toxic spills, or siltation from forest clear-cut or highway construction, are also frequent in densely populated areas like the Basque Country. Both natural and artificial disturbances affect stream biota, and the communities can only recover through recolonization, which can be negatively affected by the many barriers present in Basque streams, like dams, polluted areas, or reaches affected by water extraction. The Province Governments of Biscay and Guipuscoa are nowadays making a big effort to build fish ladders, remove non-operating dams, and ensure in-stream flows, but the problem of stream connectivity is far from solved. The sharp decline of some endangered species (e.g., Pyrenean desman, Álvarez et al., 1985; González-Esteban et al., 2003) in a period of improvement of water quality point to the fact that stream habitats are still being degraded, and to the need of considering population dynamics in the whole stream network. In this context of spatial relationships, we must stress the tight relationship between human activities in the basin and stream status. This has been well 
known for a long time, but its implications are often neglected in real management. Aspects that should be incorporated into landscape planning include restrictions to forestry and roadbuilding activities in sensitive basins (e.g., feeding reservoirs), localisation of farms with large amounts of livestock, effects of impervious areas on basin hydrology, and so on.

\section{ACKNOWLEDGEMENTS}

The group of Stream Ecology at the University of the Basque Country has been funded through the years with several projects by our university (UPV 118.310-0067/88; UPV 118.310-EA 154/92; UPV 118.310-EA 043/93; UPV 118.310EA 113/95; UPV 118.310-EC 23/97; UPV118.310G14/99; 9/UPV00118.310-14476/2002), by the Basque Government (PIGV 8924), by the Spanish Government (DGICYT PB 92-0459; DGICYT PB 95-0498; DGESIC PB98-0151; MCYT BOS2003-04466), and by the European Union (EVK1-CT-2001-00088). Many people took part in the research, via post-doctoral grants (Bosco Imbert), with doctoral grants (Raúl Bañuelos, Joserra Díez, Javier Galán, Esther González, Jose Manuel González, Oihana Izagirre, Santiago Larrañaga, Aitor Larrañaga, Jon Molinero, Ainhoa Otermin, Pilar Riaño, Joseba Santiago), through MsC Thesis (Xabi Arana, Arantza Arechederra, Lide Aristegi, Txomin Bargos, José Barquín, Ainhoa Beltrán de Nanclares, Elsa Milena Cabrera, Nicola Crosby, Joxemari Gonzalez, Arantzazu López de Luzuriaga, Javier Pérez, Amelia Rubio), as well as many assistant students. Our thanks also to the Confederación Hidrográfica del Norte, Instituto Nacional de Meteorología, Basque Government, and the Province Governments of Biscay and Guipuscoa, for data and support.

\section{REFERENCES}

ÁlVAREZ, J., A. BEA, J. M. FAUS, E. CASTIEN \& I. MENDIOLA. 1985. Atlas de los vertebrados continentales de Alava, Vizcaya y Guipúzcoa (excepto Chiroptera). Gobierno Vasco. Vitoria. $336 \mathrm{pp}$

ANONIMOUS. 1995. Euskal Hiztegi Entziklopedikoa. Klaudio Harluxet Fundazioa, 3292 pp.

ARLUZIAGA, I. 2002. Variación de la calidad de las aguas de los ríos gipuzkoanos al cabo de veinte años (19981-2000). Munibe. Ciencias Naturales, 53: 39-56.

BASAGUREN, A. \& J. POZO. 1994. Leaf litter processing of alder and eucalyptus in the Agüera stream system (northern Spain). II Macroinvertebrates associated. Arch. Hydrobiol., 132: 57-68.

BASAGUREN, A., A. ELOSEGUI \& J. POZO. 1996. Changes in the trophic structure of benthic macroinvertebrate communities associated with food availability and stream flow variations. Int. Rev. Ges. Hydrobiol., 81: 1-12.

BASAGUREN, A., P. RIAÑO \& J. POZO. 2002. Life history patterns and dietary changes of several caddisfly (Trichoptera) species in a northern Spain stream. Arch. Hydrobiol., 155: 23-41.

BASQUE GOVERNMENT. 2003. Red de vigilancia de las masas de agua superficial de la Comunidad Autónoma del País Vasco. Gobierno Vasco. $2405 \mathrm{pp}$.

CANHOTO, C. \& M. A. S. GRAÇA. 1999. Leaf barriers to fungal colonization and shredders (Tipula lateralis) consumption of decomposing Eucalyptus globulus. Microbial Ecol., 37: 163-172.

DÍEZ, J. R., S. LARRAÑAGA, A. ELOSEGI \& J. POZO. 2000. Effect of removal of woody debris on streambed stability and retention of organic matter. J. N. Am. Benthol. Soc., 19: 621-632.

DÍEZ, J. R., A. ELOSEGI, E. CHAUVET \& J. POZO. 2002. Breakdown of wood in the Agüera stream. Freshwat. Biol., 47: 2205-2215.

ELOSEGI, A. \& L. B. JOHNSON. 2003. Wood in streams and rivers in developed landscapes. In: The ecology and management of wood in World rivers. S.V. Gregory, K. L. Boyer \& A. M. Gurnell (eds.): 337-354. American Fisheries Society, Bethesda, MD.

ELOSEGI, A., A. BASAGUREN \& J. POZO. 2002. Ecology of the Agüera: a review of fourteen years of research in a Basque stream. Munibe, 53: 15-38.

ELOSEGUI, A. 1992. La cuenca del Agüera: escalas de variabilidad físico-química de las aguas y aproximación al análisis del metabolismo fluvial. $\mathrm{PhD}$ dissertation, University of the Basque Country. $181 \mathrm{pp}$.

ELOSEGUI, A. \& J. POZO. 1994. Spatial versus temporal variability in the physico-chemical cha- 
racteristics of the Agüera stream (North Spain). Acta Oecol., 15: 543-559.

ELOSEGUI, A. \& J. POZO. 1998. Epilithic biomass and metabolism in a north Iberian stream. Aquat. Sci., 60: 1-16.

ELOSEGUI, A., X. ARANA, A. BASAGUREN \& J. POZO. 1995. Self-purification processes in a medium-sized stream. Environmental Management, 19: 931-939.

ELOSEGUI, A., E. GONZÁLEZ, A. BASAGUREN \& J. POZO. 1997. Water quality variability in the Agüera stream watershed at different spatial and temporal scales. In: International River Water Quality. Pollution and Restoration. G.A. Best, T. Bogacka \& E. Niemrycz (eds.): 55-68. E \& FN Spon, London, U.K.

FAIRWEATHER, P. G. 1999. State of environmental indicators of "river health": exploring the metaphor. Freshwat. Biol., 41: 211-220.

GALERA, A. \& A. ANTÓN. 2001. Situación actual del salmon atlántico en Bizkaia. In: El salmon, joya de nuestros ríos. C. García de Leániz, A. Sedio \& S. Consuegra (eds.): 83-88. Gobierno de Cantabria, Consejería de Ganadería, Agricultura y Pesca, Santander, Spain.

GESSNER, M. O. \& E. CHAUVET. 2002. A case for using litter breakdown to assess functional stream integrity. Ecol. Appl., 12: 498-510.

GONZÁLEZ, E. \& J. POZO. 1995. El carbono orgánico disuelto en el río Agüera (Norte de España) en condiciones de estabilidad hidrológica. Limnetica, 11: 57-62.

GONZÁlEZ, J. M., A. BASAGUREN \& J. POZO. 2003a. Macroinvertebrate communities along a third-order Iberian stream. Ann. Limnol. -Int. J. Lim., 39: 287-296.

GONZÁlez, J. M., A. BASAGUREN \& J. POZO. 2003b. Life history and production of Epeorus torrentium Eaton (Ephemeroptera: Hepageniidae) in a North Iberian Stream. Aquatic Insects, 25: 247-258.

GONZÁlEZ, J. M., A. BASAGUREN \& J. POZO. 2003c. Life history, production and coexistence of two leptophlebiid mayflies in three sites along a Northern Spain stream. Arch. Hydrobiol., 158: 303-316.

GONZÁLEZ-ESTEBAN, J., I. VILLATE \& E. CASTIÉN. 2003. A comparison of methodologies used in the detection of the Pyrenean desman $G a$ lemys pyrenaicus (E. Geoffroy, 1811). Mammal. Biol., 68: 387-390.

GRAÇA, M. A. S, J. POZO, C. CANHOTO \& A. ELOSEGI. 2002. Effects of Eucalyptus planta- tions on detritus, decomposers and detritivores in streams. TheScientificWorld, 2: 1173-1185.

HAYCOCK, N. E., G. PINAY \& C. WALKER. 1993. Nitrogen retention in river corridors: European perspective. Ambio, 22: 340-346.

HORNBERGER, G. M. \& M. G. KELLY. 1975. Atmospheric reaeration in a river using productivity analysis. J. Environ. Eng. Div. ASCE, 101: 729-739.

IMBERT, J. B., J. M. GONZÁLEZ, A. BASAGUREN \& J. POZO. 2005. Influence of inorganic substrata size, leaf litter and woody debris removal on benthic invertebrates resistance to floods in two contrasting headwater streams. Internat. Rev. Hydrobiol., 90: 51-70.

IZAGIRRE, O. \& A. ELOSEGI. 2005. Environmental controls of seasonal and inter-annual variations of periphytic biomass in a north Iberian stream. Ann. Limnol. -Int. J. Lim., 41: 35-46.

IZAGIRRE, O., M. BERMEJO, J. POZO \& A. ELOSEGI. In press. RIVERMETC: an Excel-based tool to calculate river metabolism from diel oxygen concentration curves. Environmental Modelling \& Software.

KAIL, J. \& D. HERING. 2005. Using large wood to restore streams in Central Europe: potential use and likely effects. Landscape Ecol., 20:755-772.

KARR, J. R. 1981. Assessment of biotic integrity using fish communities. Fisheries, 6: 21-27.

LARRAÑAGA, S., J. R. DÍEZ, A. ELOSEGI \& J. POZO. 2003. Leaf retention in streams of the Agüera basin (northern Spain). Aquat. Sci., 65: 158-166.

MADDOCK, I. 1999. The importance of physical habitat assessment for evaluating river health. Freshwat. Biol., 41: 373-391.

MERRITT, R. W. \& K. W. CUMMINS. 1996. An introduction to the Aquatic Insects of North America. ${ }^{3 r d}$ ed. Dubuque Iowa: Kendall/Hunt Publ. Co.

MOLINERO, J. \& J. POZO. 2002. Impact of eucalypt plantations on the benthic storage of coarse particulate organic matter, nitrogen and phosphorus in small streams. Verh. Internat. Verein. Limnol., 28: 540-544.

MOLINERO, J. \& J. POZO. 2004. Effects of a eucalyptus (Eucalyptus globulus Labill.) plantation on the nutrient content and dynamics of coarse particulate organic matter (CPOM) in a small stream. Hydrobiologia, 528: 143-165.

MOLINERO, J., J. POZO \& E. GONZALEZ. 1996. Litter breakdown in streams of the Agüera catchment: influence of dissolved nutrients and land use. Freshwat. Biol., 36: 745-756. 
MUNNÉ, A., C. SOLÀ \& N. PRAT. 1998. QBR: Un índice rápido para la evaluación de la calidad de los ecosistemas de ribera. Tecnología del Agua, 175: 20-37.

ODUM, H. T. 1956. Primary production in flowing waters. Limnol. Oceanogr., 2: 85-97.

OTERMIN, A., A. BASAGUREN \& J. POZO. 2002 Re-colonization by the macroinvertebrate community after a drough period in a first-order stream (Agüera basin, northern Spain). Limnetica, 21: 117-128.

POZO, J. 1993. Leaf litter processing of alder and eucalyptus in the Agüera stream system (North Spain) I. Chemical changes. Arch. Hydrobiol., 127: 299-317.

POZO, J., A. ELOSEGUI \& A. BASAGUREN. 1994. Seston transport variability at different spatial and temporal scales in the Agüera watershed (North Spain). Water Res., 28: 125-136.

POZO, J., E. GONZÁLEZ, J. DÍEZ \& A. ELOSEGI. 1997. Leaf-litter budgets in two contrasting forested streams. Limnetica, 13: 77-84.

POZO, J., A. BASAGUREN, A. ELOSEGI, J. MOLINERO, E. FABRE \& E. CHAUVET. 1998. Afforestation with Eucalyptus globulus and leaf litter decomposition in streams of northern Spain. Hydrobiologia, 373/374: 101-109.

PIÉGAY, H., K.J. GREGORY, V. VONDAREV, A. CHIN, N. DAHLSTROM, A. ELOSEGI, S.V. GREGORY, V. JOSHI, M. MUTZ, M. RINALDI, B. WYZGA \& J. ZAWIEJSKA. 2005. Public perception as a barrier to introducing wood in rivers for restoration purposes. Environ. Man., 36: 665674.

PLAFKIN, J. L., M. T. BARBOUR, K. D. PORTER, S. K. GROSS \& R. M. HUGHES. 1989. Rapid bioassessment protocols for use in streamms and rivers: Benthic macroinvertebrates and fish. USEPA, Office of Water Regulations and Standards, Washington, D.C. EPA 440-4-89-001.

RAWER-JOST, C., J. BÖHMER, J. BLANK \& H. RAHMANN. 2000. Macroinvertebrate functional feeding groups methods in ecological assessment. Hydrobiologia, 422: 225-232.

RIAÑO, P. 1998. Ciclos biológicos y ecología trófica de los macroinvertebrados del bentos fluvial (Plecoptera, Efemeroptera y Trichoptera). PhD Dissertation. University of the Basque Country. $214 \mathrm{pp}$.

RIAÑO, P., A. BASAGUREN \& J. POZO. 1993. Variaciones especiales en las comunidades de macroinvertebrados del río Agüera (País VascoCantabria) en dos épocas con diferentes condiciones de regimen hidrológico. Limnetica, 9: 19-28.

ROSGEN, D. 1996. Applied river morphology. Wildland Hydrology, Pagosa Springs, Colorado, USA. $386 \mathrm{pp}$.

ROSENBERG, D. \& V. RESH. 1992. Freshwater biomonitoring using benthic macroinvertebrates. Chapman \& Hall, NY.

SABATER, S., A. BUTTURINI, J. C. CLEMENT, T. BURT, D. DOWRICK, M. HEFTING, V. MAÎTRE, G. PINAY, C. POSTOLACHE, M. RZEPECKI \& F. SABATER. 2003. Nitrogen removal by riparian buffers along a European climatic gradient: patterns and factors of variation. Ecosystems, 6: 20-30.

YOUNG, R., C. TOWNSEND \& C. MATTHAEI. 2004. Functional indicators of river ecosystem health - an interim guide for use in New Zealand. CAWTHRON. Report No.870. Ministry for the Environment. Nelson, New Zealand. 54 pp. 